\title{
The Role of Psychological Capital on Employee's Readiness for Change in Covid-19 Pandemic Era
}

\author{
Diah Sastaviana ${ }^{1}$
}

\author{
${ }^{1}$ Atma Jaya University, Makassar, Indonesia \\ *Corresponding author. Email: dsastaviana@gmail.com
}

\begin{abstract}
This research aims to find the role of psychological capital on employees' readiness for changes during this pandemic era. The methods used in this research are quantitative correlational with measurement instrument using psychological capital and readiness for changes scale. The sampling techniques used are incidental and snowball sampling. Data collection using google form and the number of subjects obtained were 132. The data analysis technique used in the hypothesis testing was simple regression analysis. Based on the analysis results, the correlation value $\mathrm{R}=0,688$ with a significance value of $0.000(\mathrm{p}<0.01)$ means a significant relationship between psychological capital and employee readiness. The results of this study indicate that the two variables have a relatively strong relationship. The value of $\mathrm{R}$ square is 0,473 , which means that psychological capital contributes $47,3 \%$ to the readiness for changes in the workforce during the COVID-19 pandemic. This research also analyzes the relationship of each dimension of psychological capital with readiness for change. The results of the analysis show that the optimism dimension has a relationship with readiness for change with a significance value of 0.010 $(\mathrm{p}<0.05)$, and the hope dimension also has a relationship with readiness for change with a significant value of $0.000(\mathrm{p}<0.01)$. In contrast, the significance value of the self-efficacy dimension is $0.964(\mathrm{p}>0.05)$ and the dimension of resilience with a significance value of $0.454(\mathrm{p}>0.05)$ so that it does not have a direct relationship with readiness for change.
\end{abstract}

Keywords: psychological capital, readiness for changes, employee

\section{INTRODUCTION}

Organizations made some changes to fixing organizational work effectiveness to help people adapt to environmental change and behavior [1]. In Indonesia, most companies, whether owned by state/government or private companies, changed for their organization to stay still and rise back after facing the economic crisis caused by the covid-19 pandemic. Companies' changes demand employees accept the policy and new rules applied in the organization. The employee is also expected can adapt and do further work operations. Therefore employees are expected to have readiness for changes to recover the organization's economy.

Changes that the organization made were not successful if not supported by the availability of employees to change [2]. Readiness to accept new changes is called readiness for change [3]. Readiness for change is employees' psychological readiness and behavior to accept new practices, policies, and technology in the organization [3]. Readiness for change is the organizational key to success, capital to facing competition, and an essential element to the success of change implementation. If the employee in the organization has the readiness to change, then it would be easy to follow the organization's changes [4].

Readiness for change is influenced by many factors, precisely context, content, processes, and individual characteristics [5]. In this study, the researcher is willing to include the aspects of personal characteristics that are psychological capital because more suitable with the situation and condition of the research problem. Psychological capital is an individual positive psychological condition marked with four characteristics: self-efficacy, hope, optimism, and resilience [6]. An excellent psychological capital can help the employee have readiness for change not to be stressed with the organization's changes. 


\section{PSYCHOLOGICAL CAPITAL AND READINESS FOR CHANGE THEORIES}

\subsection{Psychological Capital}

Psychological capital is the individual psychological positive condition that supports reaching optimal working performance and individual working satisfaction [7]. This theory also states that psychological capital is a personal psychological positive condition that is open to development and changes [8]. Every personal-psychological capital can run into changes and development according to the situation or individual needs.

Psychological capital formed by psychological capital dimensions [9]:

a. Self-efficacy is individual beliefs or confidence against their self ability so that can increase motivation, ability, cognitive, and act to reaches the successful task

b. Hope is individual positive motivation to help determine clear goals and feel challenged to reach them and achieve the goals.

c. Optimism is an individual attitude that gratefully and see all changes in positive ways also able to see the available opportunities and focus on reaching the chance as part of goals achievements.

d. Resilience is the ability to survive and revive from negative experiences nor positive experiences so that they can have the ability to overcome changes, difficulties, and risks caused by their work.

\subsection{Readiness for Change}

Individuals' readiness for change is individual positive reactions, including beliefs and readiness to accept organizational changes [10]. Readiness for change also as mentally readiness, psychological, or individual physical to receive and participate in organizational changes. Readiness for change is also called preparation steps to start organizational changes. Individuals who are organization members who have a positive attitude to changes also show interest in participating in changes [11].

Factors that affect readiness for change [5], specifically:

a. Content is what has been changed in the organization

b. Process is how changes would do and what will be reached

c. Context is the situation changes d. Individual characteristics that included in the changes process

There is three readiness for change dimensions [3]:

a. Cognitive readiness is individual belief and thoughts to changes

b. Emotional readiness is emotional reactions or individual feeling situation to changes

c. Intentional readiness is how far individuals are willing to be included in the changes process

\subsection{The role of Psychological Capital on Employee's Readiness for Change in Covid- 19 Pandemic Era}

Employees with good psychological capital have readiness for change to changes that the organization did [12]. The results of past research show that psychological capital has a role in readiness for change [13]. Individuals who have high psychological capital will increase the individual willingness to change [14]. Therefore, this research will test the role of psychological capital in readiness for change. Employees with high psychological capital can see all things in positive ways. Thus, the employee can overcome the stress symptoms caused by their work [15].

That explanation showed that every employee must possess psychological capital in this covid-19 pandemic era. This covid-19 pandemic has caused a decrease in many economic sectors, so that organizations need to make some changes to adapt to the environment happening right now. Changes require support from the employee as the main factor of successful changes that the organization did. Organizations need readiness from employees to adapt and face changes [16]. The conclusion is that readiness for change is way better when employees have psychological capital.

Psychological capital dimensions also have a role in increasing employee readiness for change. The resiliency dimension can help employees revive from slumps and adapt to changes. The self-efficacy dimension made employees more confident to do challenging work, including development tasks, and motivated to reach success. Hope dimension makes employees more brave facing obstacles capable of achieving goals of changes. The optimism dimension ensures employees will succeed with changes [17].

The following scheme shows the pattern of relationship between psychological capital and readiness for change: 


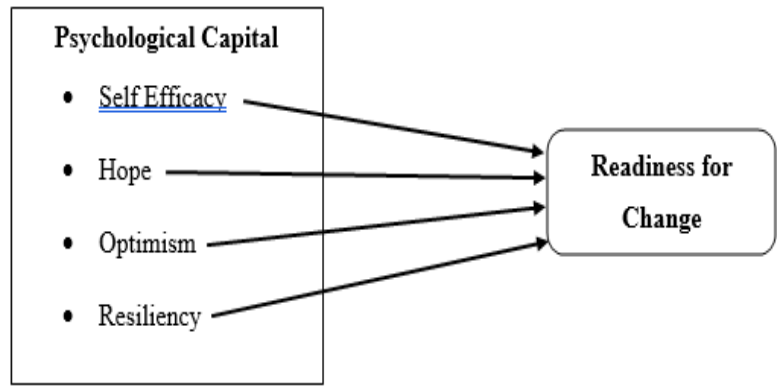

Figure 1. The Schematic of psychological capital relationship with readiness for change

The hypothesis that is willing to be answered by the researcher is.

a. Psychological capital has a role in employees readiness for change in the covid-19 pandemic era

b. Psychological capital dimensions have a relationship with readiness for change

\section{STUDY DESIGN}

\subsection{Sample and Data Collection}

The sample in this study is 132 employees working in private companies, BUMN, and state civil apparatus (ASN). Samples were obtained online using Google Forms to get subjects from various companies in various sectors. Sample collections technique using incidental techniques that are research give the instrument to all people research met, based on criteria, subject chance, and subject willingness. The study also added subject collection techniques with snowball techniques obtained from previous subjects who had connections [18].

In this study, the researchers used a trial because research implementation time is relatively short, and the researcher had some resistance in preparing research. Therefore, the data used in reliability test and total item correlation test in item research scales, also the research data were used to be analyzed by hypothesis test.

\subsection{Variable measurement}

Readiness for change variable measures using readiness for change scale compiled by research based on readiness for change dimension: cognitive readiness, emotional readiness, and intentional readiness [13]. The number of items is arranged as 18, and each dimension consists of 6 items. After trial, there is 1 item aborted, so the item used in this research are 17 items.

The psychological capital variable was measured using psychological capital dimensions compiled by research-based in psychological capital dimensions: self-efficacy, hope, optimism, and resilience [13]. The number of items is arranged as 24. Each dimension consists of 6 items. After trials, there were two aborted items, so the items used in this research were 22 items.

The instrument used in this research is Likert. The scale consists of the statement items, which are favorable and unfavorable. For favorable items, the scores move from 1 to 4 while unfavorable items move from 4 to 1. Likert scale arranged by using four answers choice with categories STS (Very Inappropriate), TS (Inappropriate), S (Suitable), SS (Very Suitable). Research not using Neutral (N) as one of the answer choices to prevent subject to choose a mid answer or safe answer.

\section{RESULT}

\subsection{The Reliability and Validity Test}

\subsubsection{Validity Test}

This research uses Corrected item-total Correlation to test the item validation coefficient. Test total correlation item used generally same valuable or bigger than 0,30. Testing was carried out using SPSS with the score for readiness for change scale with 17 items is 0,352 until 0,669 that all items declared valid. The score for psychological capital with 22 items is 0,369 until 0,644 that all items are declared valid.

\subsubsection{Reliability Test}

This research uses Cronbach's Alpha to test reliability. The reliability coefficient moves from 0 to 1 , and the more it approaches number 1, the higher the reliability coefficient. The test was done by using SPSS and the results show that the readiness for change scale has Cronbach's Alpha value of 0,885 and psychological capital is 0,906 . The test scores are more than 0,7 . Therefore it's reliable and can be used in research.

\subsection{Assumption Test}

The results of the assumption test show Kolmogorov-Smirnov value as much as 0,058 with significant value as much as $0,200(p>0,05)$, so the research data spread distribution declared normal. The result of the Linearity test also shows value is 0,000 $(p<0,01)$, meaning there's a correlation between two variables stated linear. Therefore, research data has fulfilled the assumption test as a condition for using Simple Regression Analysis. 


\subsection{Hypothesis Testing}

The analysis data shows a significant relationship between psychological capital and employee readiness for change in the covid-19 pandemic era. It can be seen from the considerable value or $p$-value as 0,000 $(\mathrm{p}<0,01)$ and the amount of correlation value between the two variables is R-value as 0,688 so that it can be declared there is a strong relationship between psychological capital with readiness for change. The hypothesis test result also shows $\mathrm{R}$ square value is 0,473 , which means psychological capital contributed as much as $47,3 \%$ to readiness for change employees in this covid-19 pandemic era. That means psychological capital has a role in employee readiness for change.

This research also analyzes every relation from psychological capital dimensions with readiness for change. The analysis result shows optimism dimension have a relation with readiness for change with a significant value of $0,010(\mathrm{p}<0,05)$ and the hope dimension also have a relation with readiness for change with a significant value of $0,000(p<0,01)$. The significant value of the self-efficacy dimension is $0,964(\mathrm{p}>0,05)$ and resilience with a significant value of $0,454(p>0,05)$, so that shows there do not have relation directly with readiness for change.

The researcher also tested a relation based on the demographic aspect that is sex, jobs, education, and age with psychological capital and readiness for change. The result shows sex and age have a relationship with psychological capital, with a significant value of sex being $0,038(\mathrm{p}<0,05)$ and a significant value of age being $0,040 \quad(\mathrm{p}<0,05)$. Whereas job and education don't have a relationship with psychological capital. Significant value of job is $0,347(p>0,05)$ and education significant value is $0,701(\mathrm{p}>0,05)$.

The result obtained in the relation test between sex and readiness for change shows a significant value of $0,790(\mathrm{p}>0,05)$ so that it can be declared that sex and readiness for change don't have a relationship. Another aspect that doesn't relate to readiness for change is education, with a significant value of 0,485 ( $p>0,05)$. Whereas job and age have a relationship readiness for change. Job significant value is $0,010(\mathrm{p}<0,05)$ and age significant value $0,007(\mathrm{p}<0,05)$.

\section{DISCUSSION}

The hypothesis test obtained R-value as much ad 0,688 with a significant value of $0,000<0,01$ so that these two variables that are psychological capital and readiness for change, have a strong relation. Therefore, employee psychological capital in the covid-19 pandemic era has a role in readiness for change. $\mathrm{R}$ square value in this research is 0,473 . The result describes that psychological capital contribution to employee readiness for change as much as $47,3 \%$. Therefore, in conclusion, the employee needs psychological capital to have readiness for change in work, especially facing changes during the covid-19 pandemic.

The result is in line with past research that shows psychological capital, alongside psychological empowerment, takes a role in individual readiness for change. When individuals have psychological capital, individual readiness for change can be increased [8]. Psychological capital plays a role in increasing readiness for change through psychological capital dimensions that is self-efficacy, hope, optimism, and resilience [11]. Based on this past research result, so in conclusion, individuals need to increase psychological capital by managing and strengthening self-efficacy, hope, optimism, and resilience so that readiness for change to facing organization changes, significantly higher chance during the covid-19 pandemic era.

This research also shows the contribution of psychological capital to readiness for change as much as $47,3 \%$, while $52,7 \%$ of results are roles from other variables that were not researched. Past research result shows that psychological capital has a role as much as $27 \%$ in increasing readiness for change while $73 \%$ is variables that are not involved in research [11]. Therefore, in conclusion, other variables can affect readiness for change.

The explanation also can be seen in this research, where the result of subject score categories in two variables shows the majority of research subjects have psychological capital scores classified as high. Most of the research subject's readiness for change score is at high and medium. That result means a research subject has high psychological capital but a middle category for readiness for change. That can happen because research subjects come from different jobs and workplaces, so their readiness for change can be affected by various factors in every organization.

The research result states that organization support perception relates to readiness for change [19]. In conclusion, that employee readiness for change, affected by organization support perception so that employees who come from different organizations will have different perceptions of organization support and readiness for change result will be other. That explanation is in line with this research result that field of work that is different companies have a relation with readiness for change with significant value 0,010 $(\mathrm{p}<0,05)$. Different companies can build different employee perceptions to have other readiness for change. 
This result also measures every psychological capital dimension with readiness for change. The results show that not all psychological capital dimensions relate to readiness for change separately. Therefore, the employee needs to increase whole psychological capital in all dimensions to increase readiness for change. Psychological capital will optimally increase readiness for change if all dimensions are put together.

Based on the explanation above, psychological capital roles are significant to increasing readiness for change. Readiness for change is indispensable for employees, especially in this covid-19 pandemic era, where every organization must make some changes to survive and develop. Organizational changes need readiness for change from every employee so that psychological capital will become one variable that needs to be upgraded.

\section{CONCLUSION}

The conclusion from the analysis data and research interpretation result is a significant relationship between psychological capital and readiness for change. Psychological capital contribution to readiness for change as much ad $47,3 \%$. That result means that psychological capital can enhance readiness for change. Another variable that plays a role in readiness for change is not included in the research as $52,7 \%$. This result described in subject score on the psychological capital variable majority is on high category while scoring on readiness for change variable majority classified high and medium. It means not all subjects with high psychological capital also have high readiness for change. Another variable plays a role in increasing readiness for change in this research, one of them caused by research subjects from a different organization.

Based on the conclusion that has been present, so suggestions for the following similar research with this research is:

a. Trials measuring instrument subject and research subject are distinguished to make the research scale more accurate.

b. The next researcher also recommended researching readiness for change with another independent variable that maybe have a more significant contribution to readiness for change.

\section{AUTHORS' CONTRIBUTIONS}

The researcher is task research, so the role in this research is the corresponding author and responsible for this research.

\section{ACKNOWLEDGMENTS}

This research supported by the Faculty of Psychology, Atma Jaya University Makassar

\section{REFERENCES}

[1] Robbins, S. P., \& Judge, A. T.. Organizational behavior. Essex: Pearson Educated Limited. 2013.

[2] Ochieng, J., Muturi, D., Douglas, A., \& Douglas, J. Organizational Climate and readiness for change to Lean Six Sigma. Researchgate. 2015. DOI: $10.13140 /$ RG.2.1.5131.4085

[3] Helfrich, C. D., Kohn, M.J., Stapleton, A., Allen, C.L., Hammerback, K. E., Chan, G., Parrish, A.T., Ryan, D. E., Weiner, B. J., Harris, J.R., \& Hannon, P. A. Readiness to change Over Time: Change Commitment and Change Efficacy in a Workplace healthPromotion Trial. Frontiers in Public Health. 2018. 6(110).

[4] Matthysen, M., \& Hariis, C. The Relationship Between Readiness To Change And Work Engagement: A Case Study In An Accounting Firm Undergoing Change. SA Journal Of Human Resource Management. 2018. 16(0), $\mathrm{A} 855$.

Https://Doi. Org/10.4102/Sajhrm.V16i0.855

[5] Holt, D. T., Armenakis, A., Feild, H. S., \& Harris, S. G. Readiness for Organizational Change: The Systematic Development Of A Scale. Journal of Applied Behavioral Science. 2007. 43, Hal. 232- 255.

[6] Luthans, F., Youssef, C. M., \& Avolio, B. J. Psychological Capital: Developing the Human Competitive Edge. New York: Oxford University Press. 2007.

[7] Avey, J. B., Luthans, F., Smith, R. M., \& Palmer. Impact of Positive Psychological Capital on Employee Well Being Over Time. Journal of Occupational Health Psychology. 2010. 15(1), Hal. 17 - 28.

[8] Luthans, F., Avolio, B. J., Avey, J. B., \& Norman, S. M. Positive Psychological Capital: Measurement and Relationship with Performance and Satisfaction. Personal Psychology, 2007. 60, Hal. 541 - 572.

[9] Luthans, F., Youssef, C. M., \& Avolio, B. J. Psychological Capital: Developing the Human Competitive Edge. New York: Oxford University Press. 2007. 
[10] Bouckenooghe, D., Devos, G \& Broeck, H.V. Organizational Change Questionnaire-Climate of Change, Process and Readiness: Development of a New Instrument. Journal of Psychology, 2009. 6(143), Hal. 559-599.

[11] Pranatha, N. R. D., \& Majorsy, U. Komitmen Organisasi dan Kesiapan Untuk Berubah Pada Tenaga kerja Media Cetak. Jurnal Psikologi Universitas Gunadarma, 2018. 11(1), Hal. $25-$ 35.

[12] Lizar, A. A., Mangundjaya, W. L.H \& Rachmawan, A. The Role of Psychological Capital and Psychological Empowerment on Individual Readiness For Change. Journal of Developing Areas, 2015. 49(5), Hal. 343-352.

[13] Jabbarian, J., \& Chegini, M. G. The Effect Of Perceived Organizational Support On Employee Resistance To Change: A Study On Guilan Municipal Staff. Journal of History Culture and Art Research, 2016. 5(4), Hal 642-654.

[14] Sasmita, I. A. G. H. D, The Effect of Transformational Leadership and Psychological Capital to Individual Readiness to Change for Employees in Tourism Development Corporate. Journal Psikodimensia, 2019. 18(2), Hal. 167 - 177.

[15] Çavus, M. F., \& Gokcen, A. Psychological Capital: Definition, Components and Effect. British Journal of Education, Society \& Behavioural Science, 2015. 5(3), Hal. 244 255.

[16] Anggraini, N. P., \& Fajriathi. Peran Psychological Capital dalam Hubungan Persepsi Dukungan Manajemen dan Kesiapan untuk Berubah. Jurnal Psikologi Teori dan Terapan, 2019. 10(1), Hal. 85-94.

[17] Munawaroh, L., \& Meiyanto, S. Peranan Psychological Capital terhadap Kesiapan Individu untuk Berubah yang Dimoderatori oleh Persepsi Dukungan Organisasi. Jurnal Psikologi. 2017. 44(3), Hal. 198 - 210.

[18] Periantalo, J. Penelitian Kuantitatif Untuk Psikologi. Yogyakarta: Pustaka Belajar. 2016.

[19] Ningrum, O., A \& Salendu, A, Pengaruh Psychological Capital terhadap Individual Readiness for Change pada Tenaga kerja Sales. Jurnal Diversita. 2021. 7(1), Hal. 53-62. 